IV.-Mineralogicat. Society.

March 11, 1913.-Professor H. L. Bowman, Vice-President, in the Chair.

W. Campbell Smith : The Mineral Collection of Thomas Pennant (1726-98). The collection, which has recently been presented to the British Museum by the Earl of Denbigh, is accompanied by three volumes of manuscript catalogue, written in 1757 . The classification used in them is based with some modifications on Woodward's Natural History of the Fossils of England, published in 1729. Special mention is made of specimens presented by Borlase, Pontoppidan, and Da Costa, and the minerals from Flintshire were treated in some detail. Several specimens were described by Pennant in $A$ Tour in Wales.-Arthur Russell: The Minerals and Mineral Localities of Montgomeryshire. of the species described the more remarkable are aurichalcite, from Llanymynech Hill Mine, Llanymynech; harmotome in double twins, associated with barytes and witherite, from $\mathrm{Cwm}$-orog Mine, Llangynog; hydrozincite, which forms a remarkable recent deposit on the sides of a level in the Van Mine, Llanidloes; pyromorphite from Aberdeunant Mine, Llanidloes, and Llanerch-yr-aur Mine, Llanbrynmair; witherite from Cwm-orog Mine, Llangynog, Gorn Mine, Pen-y-Gaer Mine, and Pen-y-Clyn Mine, Llanidloes, the crystals from the last being noteworthy on account of the almost entire suppression of the alternate faces of the pseudohexagonal prisms and pyramids.-Dr. G. F. Herbert Smith: A new Stereographic Protractor. The novelty consists of a curved ruler, made up of a combination of springs, which sensibly retains a circular curvature within the limits for which it is required. At the centre of the arc it is clamped to an arm, movable in a groove and carrying a scale, from which the azimuth of the corresponding great circle may be read off. The other edge of the protractor carries the usual tangent scales, from which the position of the compass to draw any circle up to the one corresponding to the great circle making an azimuth of $50^{\circ}$ with the equatorial plane may be determined. The scales are based upon a radius of $10 \mathrm{~cm}$.- - L. J. Spencer: A (sixth) List of new Mineral Names.

\title{
COREESPONDENOF.
}

\section{THE AGE OF THE TORBAY RAISED BEACHES.}

SIR,-If Mr. A. R. Hunt desires to be an effective critic and not a mere needless fault-finder, he should not base an argument on ancient history and ignore modern research. He thinks it "unfortunate" that in dealing with the evidence of raised beaches in a recent paper on "The Making of Torbay" I made no reference to the "voluminous literature" concerning them, and he writes as if he supposed there had been no change of opinion about them since the discussion which took place at the Geological Society in $\mathbf{1 8 9 0 .}$

Apparently he has not realized that the whole question of the age of the raised beaches in Devon and Cornwall has entered an entirely new phase since the discovery that the raised beach of Gower (in 
South Wales) is older than the local glacial deposits. That discovery was made by R. H. Tiddeman in 1900, and was published in this Magazine for that year. ${ }^{1}$ Moreover, in 1903 Messrs. Wright and Muff (Maufe) proved that the 12 to $15 \mathrm{ft}$. raised beach in the South of Ireland was also relatively pre-Glacial. These observers have shown that the descending succession in both countries is as follows :-

Upper head or local rubble.

Glacial deposits.

Lower head and cave earth.

Raised beach.

In Devon and Cornwall the succession is the same where most complete, but is usually without any glacial deposit, because the area was probably outside the limits of continuous ice even at the epoch of maximum glaciation. An accumulation has, however, been found above a raised beach in the Scilly Isles, which Mr. Barrow has not hesitated to describe as "a glacial deposit", and his final remarks regarding it are so much to the point that $I$ may be excused for quoting them. He says: "The occurrence of this [deposit] is of the utmost importance, for not only can the old beach be now seen to be identical with that on the Cornish coast, but it is obviously contemporaneous with that described by Messrs. Wright \& Muff(Maufe) occurring on the south coast of Ireland. It is also identical with that occurring in the South Wales area, for in both instances the head overlying the old beach is capped by a Glacial deposit. Thus, then, the old beaches in the Scilly Isles, in Cornwall, in South Wales, and in the South of Ireland are not only contemporaneous, but in addition are older than part of the Glacial Deposits" (The Geology of the 18les of Scilly, Mem. Geol. Survey, 1907). To this I need only add that Mr. Ussher has accepted the same date for the raised beaches near Plymouth (Mem. Geol. Survey, 1907). Naturally, therefore, in dealing with "The Making of Torbay" I thought it was sufficient to state that the age of the raised beaches in Devonshire had been so determined, and consequently I did not refer to the ancient history of the question.

Mr. Hunt, however, is bold enough to assert that " the intrinsic evidence of the Torbay beaches against an early glacial antiquity is very strong", and he indicates three lines of evidence, riz. those of flint implements, Molluscan fauna, and geographical position. He says that flints of recognized Neolithic age have occurred "at Hope's Nose in Torbay, in the Irish beaches, and in the Scotch beaches, all within the 25 foot level or terrace". Now, if by the words "at Hope's Nose" he means in the material of the beach we should like to have particulars of the find. The neolith obtained from the floor of Torbay proves nothing, neither do the finds in the raised beach of Antrim or in the Scotch $25 \mathrm{ft}$. beach, because it has been shown that the land-movements in the north were quite different from those in the south-west of the British area.

Mr. Hunt's second argument, based on the non-Arctic character of the Molluscan fauna, is specious but fallacious, because we have no standard of comparison within the areas of the English and Bristol

1 GeOL. MAG., 1900, pp. 441-3. 
Channels, and we do not know how much the Molluscan assemblage in the Channel waters was affected by the cold of the Glacial Period. If $I$ am right in believing that the Straits of Dover did not exist at the time when the raised beaches were formed, and that the Channel Sea was then a gulf opening westward, it is probable that the temperature of the water was never very much lowered, and that its fauna underwent very little change from early Pleistocene time to the present day.

With regard to Mr. Hunt's geographical facts, I quite fail to see their bearing or why a beach at Hope's Nose should "represent a very much later stage of coast erosion" than one at Portland Bill.

The matter stands thus: It is not a case of all the available evidence tending to show that $I$ did not know what $I$ was writing about; the geological facts are as I have stated above, and if Mr. Hunt declines to accept the inferences that other people have drawn from them, he will have to adduce much more defnite and cogent reasons for his disbelief. It will certainly take all he can get out of "geography, conchology, physics, palæontology, archæology, anthropology, and micro-petrology" to upset the geological evidence!

In 1905 he had to admit that he had completely misunderstood one important particular in Messrs. Wright \& Muff's (Maufe's) account of the Cork raised beach, and it now looks as if he had quite failed to realize its bearings in another direction.

A. J. JukEs-Browne.

P.S.-Since writing the above $\mathrm{I}$ have discovered what Mr. Hunt meant by his reference to a Neolithic flint "at Hope's Nose". It is recorded in one of his own papers, ${ }^{1}$ and, as I suspected, it was not found in the beach itself. His words are: "I noticed a flint flake jutting out of a stratum of landwash at the top of the little cliff just east of the Hope's Nose beach. It was about two feet below the surface. With it there were three other fragments and two littorina shells. I sent the flake with one of the smaller pieces to Sir John Evans, K.C.B., who replied: 'Both the enclosed seem to be artificially made flakes probably of Neolithic date.' As there are some flints in the raised beach, it seems possible that these flakes were made on the spot." It is evident, therefore, that Mr. Hunt knew that the flint was only a flake, and that it did not occur in the material of the beach but in landwash above it; yet he blandly quotes its occurrence as an argument against the early Pleistocene age of the beach! It will be interesting to learn what explanation Mr. Hunt has to offer.

Westleigh, Ash Hitl Road, Torquay.

$$
\text { A. J. J.-B. }
$$

\section{AGE OF RAISED BEACHES.}

SIr,--In an ingenious classification of the Raised Beaches and associated deposits of the South and West of England, Mr. H. Dewey (Geoc. MaG., A pril, 1913, pp. 154-63) refers to similar beaches in the South of Ireland and brings them within his scheme. By a roundabout argument from their hypothetical relationship to the Thames

\footnotetext{
1 Trans. Devon Assoc., vol. zxxvi, p. 475, 1905.
} 